\title{
MASTURBATION IN THE IN VIVO TREATMENT OF IMPOTENCE
}

\author{
DAVID SUE* \\ Department of Psychology, University of Michigan, Dearborn
}

\begin{abstract}
Summary-Masturbation was successfully employed in a desensitization-like procedure to eliminate primary impotence in a $24-\mathrm{yr}$-old male. Follow-up at one, three, and six months showed no recurrence of the problem. The potential of masturbation as a competing response is discussed.
\end{abstract}

Although masturbation has been successfully used to treat sexual dysfunction in women (Kohlenberg, 1974; LoPiccolo and Lobitz, 1972; Reisinger, 1974), there have been few reports on employing this technique to treat similar problems in men. Masturbation does seem to be effective in changing fantasies and sexual object choice in males (Davison, 1968; Freeman and Meyer, 1975; Marquis, 1970) and has been used to eliminate avoidance behaviors and anxieties associated with certain social fears (Clopton and Risbrough, 1973).

The use of sexual arousal in the treatment of sexual disorders in males is certainly not new. Wolpe $(1958 ; 1973)$ suggested and found the "deliberate use of anxietyinhibiting effects of erotic arousal" an effective procedure in treating erectile difficulties in males. Bass (1974) found erotic fantasies interposed with anxiety eliciting scenes effective in treating a case involving secondary impotence. According to Wolpe's formulation, the stronger the competing responsc, the more rapid the desensitization. Theoretically, if a male is very highly aroused or near orgasm when facing a fearful situation, the anxiety will have less impact and be more rapidly eliminated. The present case study illustrates the use of a sexual arousal method, masturbation, in the treatment of primary impotence.

\section{CASE HISTORY}

The client was a 24-yr-old male who complained of erectile difficulties since his first attempt at coitus at the age of 18. The first episode was filled with anxiety and his failure to obtain an erection "haunted him" during subsequent sexual encounters. He was living with a girl friend who attended all of the sessions with him. The client reported infrequent erections when sitting near his partner or lying in bed next to her. However, these would be lost as soon as she attempted to create further sexual arousal in the client. She had tried oral and manual means to arouse the client without success.

The couple was quite knowledgeable about the literature on sexual dysfunction and had purchased several treatment manuals. They reported "trying out" various procedures for several months and became discouraged with the lack of positive results. The client was especially concerned sincc the transient erections seemed to be occurring even less frequently. To attain sexual release, the client masturbated when alone approximately four times a week. The woman was sexually responsive and reported being satisfied with orgasms obtained through oral and manual means.

\section{TREATMENT}

Treatment procedures were similar to those described by Wolpe $(1958,1973)$ : (1) The role of anxiety and the com-

Table 1. Hierarchy of in vivo desensitization exercises

(1) Male and female lying in bed. Male masturbates to orgasm on his side, facing away from the female.

(2) Male masturbates in side position. When near orgasm, he signals his partner (touching her) who caresses him from behind. Orgasm occurs.

(3) Male masturbates in side position and signals his partner to caress him earlier in the orgasmic sequence.

(4) Male masturbates to orgasm with his partner kissing him and caressing him from the beginning.

(5) Male masturbates in side position. When near orgasm, he signals his partner who masturbates him to orgasm.

(6) Female partner masturbates male to orgasm earlier in the sequence.

(7) Female masturbates male to orgasm without any assistance.

(8) Female masturbating male who is on his back. When near orgasm, she adopts the female superior position and places his penis in her vagina.

(9) Female masturbates male and places his penis in her vagina earlier in the sequence and moves until orgasm occurs.

(10) After arousal, male initiates sexual intercourse, moving until orgasm.

(11) Male initiates sexual intercourse, moving until orgasm.

* Requests for reprints should be addressed to David Sue, Department of Psychology, University of Michigan, Dearborn, Michigan 48128. 
peting nature of sexual arousal through masturbation were explained. At this time, both partners' attitudes towards masturbation were examined; (2) A hierarchy was constructed involving in vivo practice exercises and is presented in Table 1. During these practice sessions, the client was asked to think about his most erotic fantasies during masturbation and to discontinue if any anxiety was experienced. It was explained that temporary setbacks could occur if the anxiety level was too high. Although the client was instructed to choose any sexual fantasies he found erotic during masturbation, most of them revolved around the sessions with his partner, who similarly reported finding these exercises arousing to her. The client was also instructed not to masturbate outside of their practice sessions, and to relieve his partner of her sexual tension by their usual means.

Bi-weekly phone contacts with the client as well as one meeting per week allowed for the assessment of progress and the assignment of the next hierarchy item for practice. The exercises were performed by the couple five days a week.

\section{RESULTS AND DISCUSSION}

By the end of the third week, the couple reported their first instance of sexual intercourse. At follow-up contacts of one, three, and six months post-treatment, the client reported no further problems with erectile difficulties and commented that their entire relationship had improved.

The results indicate that masturbation may prove useful as an alternative to present methods of treating impotence. Masters and Johnson (1970), for example, report a failure rate of over $40 \%$ in the treatment of primary impotence. In contrast to current methods, masturbation produces a rapid and sustained high level of sexual arousal which can serve as a more effective competing response to anxiety.

Although masturbation is a promising technique in treating impotence, its major disadvantage is the guilt that is often associated with this practice (Marshall, 1975). In the instances where feelings of guilt regarding masturbation may be strong, individuals may require desensitization before this technique can be employed. However, its potential as an additional means to treat erectile difficulties in males would seem to out weigh this disadvantage.

\section{REFERENCES}

Bass B. A. (1974) Sexual arousal as an anxiety inhibitor, $J$. Behav. Ther. \& Exp. Psychiat, 5, 151-152.

Clopton J. R. and Risbrough R. F. (1973) Sexual arousal for desensitization. Behav. Therapy 4, 141-143.

Davison G. C. (1968) The elimination of a sadistic fantasy by a client-controlled conditioning technique: a case study. J. abnorm. Psychol. 73, 84-90.

Freeman W. and Meyer R. G. (1975) A behavioral alteration of sexual preferences in the human male. Behav. Therapy 6, 206-212.

Kohlenberg R. J. (1974) Directed masturbation and the treatment of primary orgasmic dysfunction. Arch. Sex. Behav. 3, 349-356.

LoPiccolo J and Lobitz C. (1972) The role of masturbation in the treatment of sexual dysfunction. Arch. Sex. Behav. 2, 163-171.

Marquis J. N. (1970) Orgasmic reconditioning: changing sexual object through controlling masturbation fantasies. J. Behav. Ther. \& Exp. Psychiat. 1, 263-271.

Marshall W. L. (1975) Reducing masturbatory guilt. $J$. Behav. Ther. \& Exp. Psychiat. 6, 260-261.

Masters W. H. and Johnson V. E. (1970) IIuman Sexual Inadequacy. Little, Brown \& Company, Boston.

Reisinger J. J. (1974) Masturbatory training in the treatment of primary orgasmic dysfunction. J. Behav. Ther. \& Exp. Psychiat. 5, 179-183.

Wolpe J. (1958) Psychotherapy by Reciprocal Inhibition. Stanford IIniversity Press, Stanford.

Wolpe J. (1973) The Practice of Behavior Therapy. Pergamon Press, New York. 